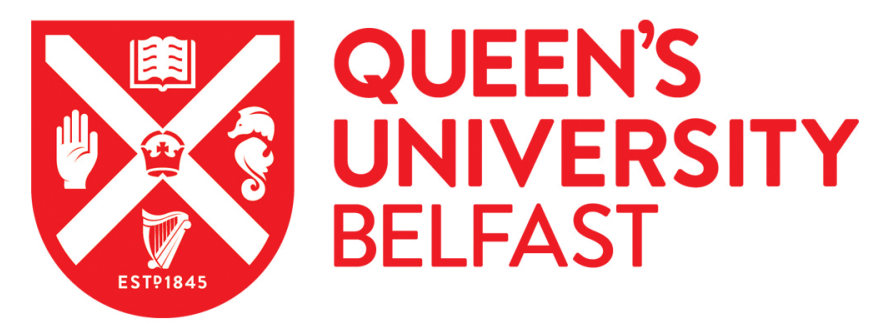

\title{
The loss of ecosystem-services emerging from artificial light at night
}

\author{
Abraham, H., Scantlebury, D. M., \& Zubidat, A. E. (2019). The loss of ecosystem-services emerging from \\ artificial light at night. Chronobiology International, 36(2), 296-298. \\ https://doi.org/10.1080/07420528.2018.1534122
}

\author{
Published in: \\ Chronobiology International
}

\section{Document Version:}

Peer reviewed version

\section{Queen's University Belfast - Research Portal:}

Link to publication record in Queen's University Belfast Research Portal

\section{Publisher rights}

(c) 2018 Taylor \& Francis Group, LLC. This work is made available online in accordance with the publisher's policies. Please refer to any applicable terms of use of the publisher.

\section{General rights}

Copyright for the publications made accessible via the Queen's University Belfast Research Portal is retained by the author(s) and / or other copyright owners and it is a condition of accessing these publications that users recognise and abide by the legal requirements associated with these rights.

Take down policy

The Research Portal is Queen's institutional repository that provides access to Queen's research output. Every effort has been made to ensure that content in the Research Portal does not infringe any person's rights, or applicable UK laws. If you discover content in the Research Portal that you believe breaches copyright or violates any law, please contact openaccess@qub.ac.uk. 
The loss of ecosystem-services emerging from artificial light at night

Haim Abrahama, David M. Scantleburyb, and Abed E. Zubidata

aThe Israeli Centre for Interdisciplinary Research in Chronobiology, University Haifa, Haifa, Israel; bSchool of Biological Sciences, Queen's

University Belfast, Belfast, Ireland

ABSTRACT

Light pollution is increasing worldwide, affecting human health and ecosystem quality. The adverse effect of this novel pollution, mediated in mammals by suppression of the pineal neuro-hormone melatonin production and secretion, particularly by short wavelength (SWL) illumination. Currently, this problem is not challenged sufficiently, even ignored by decision-makers at local and national levels,

as well as other related organizations. Therefore, we assume that the correct way to dealwith itwill be by

treating the dark night as an ecosystem-service for temporal organization of humans as other organisms.

Therefore, chasing darkness away and mainly by SWL illumination is as giving up the natural light/dark

cycles offered as an ecosystem-service. So far, we have no environmental economic tools for assessing

the real coast of the health damages or reduction in pollination caused by light pollution. Using Artificial

Light at Night (ALAN) as a loss of ecosystem-services will enable us to give it a realistic economic value

thus an opportunity to re-evaluate the environmental cost of SWL efficient illumination. This will also

help decision-makers to move to the next stage of illumination preferring sustainable illumination.

Chronobiology and melatonin

When Hall, Rosbash and Young received the

Medicine and Physiology Nobel Prize in 2017 for

elucidating the molecular basis of the biological

clock; it was also an acknowledgement of the importance

of the over 50-year-old discipline of chronobiology. 
An important step towards our understanding of timekeeping and temporal organization in mammals including humans was the discovery of the eye dual functions. In the retina while some photoreceptors form an image, other, "non-image forming" photoreceptors entrain our biological clock. The latter are particularly sensitive to short wavelength (SWL) lighting, blue (450-500 nm), which in the natural environment only occurs from morning to the afternoon. Exposure to sufficient dark period (i.e. lack of SWL), however, is crucial for the production of melatonin (MLT) (Aisling 2018). This "jack of all trades" pineal neuro-hormone which performs many essential functions including being a main signal for temporal organization of cell tissues and organs, an antioxidant, anti-aging and anti-oncogenic agent particularly important for the suppression of breast and prostate cancers (Cissé and Nelson 2016; Haim and Portnov 2013; Zubidat and Haim 2017).

Edison's incandescent light bulb, creating artificial light at night (ALAN), brought large economic and social benefits changing our lives dramatically. Only recently we are realizing how "chasing the darkness away" (Aisling 2018; Falchi et al. 2011) also has huge costs because it disrupts biological rhythms, interferes with our sleep and suppressesMLT production. The situation has become much more threatening since the 1950s, and especially in the last 10 years. Whereas early incandescent light bulbs produced minimal amounts of SWL, causing only limited disruption of MLT production3, modern sources of 
ALAN (e.g. produced by light emitting diodes

(LED)) produce much more SWL and are inescapable, pervading our public and private spaces effecting also open spaces (e.g. offices, homes, car and street lights, intercity roads, computers, TVs, smartphones, tablets etc.). This persistent exposure to SWL, typical to daytime, cause's major suppression of MLT production (Gaston et al. 2015), resulting in a negative impact on temporal organization at different levels.

Dark nights - an overlooked crucial ecosystem-service threatened by ALAN What about the environment, the third "pillar of sustainability"? (Gustafson et al. (2016). Daily (2000) characterizes naturally occurring goods such as timber, seafood and ore as well as aesthetic and cultural services that provide life fulfilment as ecosystemservices (Daily 1997, 2000). Throughout human history there has been tacit reliance on natural systems for all manner of necessities. Forests provide many resources including fuel, shelter and constructionmaterials whilst simultaneously removing atmospheric $\mathrm{CO} 2$, producing $\mathrm{O} 2$ and preventing soil degradation. However, what about darkness? A crucial element not yet included in the list of ecosystemservices is the darkness of night, without which, terrestrial organisms cannot entrain their biological clocks. The negative consequences of any change in light-dark regimes are profound. Indeed, in many species reproduction is photoperiod-dependent, so 
light pollution affects reproduction and seasonality

(Longcore and Rich 2004; Rich and Longcore 2006).

Recently, it has been demonstrated that light pollution

particularly of blue SWL also interfere with

pollination (Bennie et al. 2016; MacGregor et al.

2015). Light pollution may reduce number of visited

flowers by nocturnal pollinator and the reduced

pollination cannot by compensated by diurnal counterpart

pollinators (Knop et al. 2017). Consequently,

the loss of nocturnal pollination service is expected

to affect plants reproduction resulting in a marked

decrease in human food crop production.

Historically, much of what we understand about

environmental degradation has considered spatial

disturbances (fires, floods, droughts, disease-outbreaks);

however, far less is known about how temporal

stressors affect ecological dynamics,

presumably because these are more difficult to

observe. As ecological niches, defined by both temporal

and spatial variables, it is reasonable to assume

that ALAN affects species' biology. Moreover, when

we approached populations for energy saving and

reducing $\mathrm{CO} 2$ production for decreasing the effects

of climate change, the cost-benefit analysis we use

does not consider the cost of external expenses.

Accepting darkness at night as an ecosystem-service

will include more variables as external costs thus

reducing the benefits of LED for instance, emerging

from energy saving. If LED suppresses MLT production

to levels affecting our health than missing days

of work, visits to medical clinics or hospitals for 
treatments should be included as costs, where to the best of our knowledge is not included today. Light pollution is increasing worldwide (Figure 1). Seemingly, the biologically adverse effects of ALAN have been ignored by European governments and other, which have passed resolutions limiting the use of "inefficient" incandescent and halogen bulbs above 60W. In fact, these two sources of artificial light are much less harmful to the environment and to us than fluorescent or LED lights as they have longer wavelengths. Thus, the dilemma is how to reduce "inefficient" electric lighting whilst minimizing the harmful effects of so-called "environmentally friendly" SWL-lighting.

Because night darkness is a crucial ecosystemservice, loss of darkness is a loss of this service.

Currently assumed cost-benefit analyses which only incorporate energy savings do not adequately include any disadvantages of SWL-lighting. Adding the cost of this ecosystem-service into the cost-benefit analysis will allow us to decide how best to deliver sustainable lighting that is also truly environmentally friendly.

\section{Mitigation measures}

The adverse effect of light pollution needs to be avoided where possible and to be minimized to acceptable level where it cannot be entirely avoided. Previously, the spectra of common types of lamps for outdoor illumination were evaluated in relation to melatonin suppression (Falchi et al. 2011). In this 
study, a clear association was detected between the pollution level and the spectral composition of the lamps, with the more "environmentally friendly" being low pressure sodium, followed by high pressure sodium. Conversely, the strong blue emission lamps such as Metal Halide and white LEDs were the most significant source of light pollution (Falchi et al. 2011). Therefore, developing an "environmentally friendly" lighting technology with no blue emission is the first step in reducing the adverse impacts of light pollution on health and environment. As red lights present the least power to induce circadian disruption (Wright and Lack 2001; Wright et al. 2004), developing red LED lamps would be of a great interest regarding light pollution as such illumination may offer the power and energy efficient characteristics of the LED technology, but without blue emission at the SWLend of the visual spectrum. Furthermore, behavioural changes such as avoiding over lighting, turning off lights when they are not needed, and limiting the use of SWL-blue light, can also contribute to minimizing the adverse impact of light pollution (Falchi et al. 2011).

The way forward? There is no doubt that ALAN has greatly benefitted human society. However, there is a price to be paid both to our own health and to that of the wider environment. We cannot go back to pre-Edison days and we will continue to use incandescent, fluorescent, LED and other forms of lighting. Nevertheless, we must seek smart sophisticated solutions for the next 
generation of smarter equipment which will have to minimize the threats to the ecosystem upon which we depend. For such solutions, we need tools for assessing the negative environmental impact of exposure to SWL-light pollution. Treating darkness at night as an ecosystem-service can assist us in calculation of external costs thus demonstrating that the real cost of moving to energy efficient illumination, which is not saving the community expenses. Who will pay for medical treatment and the days we miss work included in the external expenses? Who will pay for both the reduced food production and for improving nocturnal pollination service? Therefore, the next stage of illumination should be sustainable illumination where environmental variables, social variables and there outcomes should be calculated, we do think this will be an important movement in the right direction.

Declaration of interest

The authors report no conflicts of interest.

References

Aisling I. 2018. The dark side of light. Nature. 553:268-70. Bennie J, Davies TW, Cruse D, Gaston KJ. 2016. Ecological effects of artificial light at night on wild plants. J Ecol. 104:611-20.

Cissé YM, Nelson RJ. 2016. Consequences of circadian dysregulation on metabolism. Chronophysiol Therapy. 6:55-63.

Daily GC, Editor. 1997. Nature's services: societal dependence on natural ecosystems. Washington (DC): Island Press. 
Daily GC. 2000. Management objectives for the protection of ecosystem services. Enviro Sci Policy. 3:333-39.

Falchi F, Cinzano, P, Elvidge, CD, Keith DM, and Haim A. 2011.

Limiting the impact of light pollution on human health, environment

and stellar visibility. J Environ Manage. 92:2714-22.

Gaston KJ, Visser ME, Hölker F. 2015. The biological impacts

of artificial light at night: the research challenge. Philos

Trans R Soc Lond B Biol Sci. 370:pii:20140133.

Gustafson D, Gutman A, Leet W, Drewnowski A, Fanzo J, Ingram J. 2016. Seven food system metrics of sustainable nutrition security. Sustainability. 8:196.

Haim A, Portnov BA. 2013. Light pollution as a new risk factor for human breast and prostate cancers. Dordrecht (The Netherlands): Springer Netherlands.

Knop E, Zoller L, Ryser R, Gerpe C, Hörler M, Fontaine C.

2017. Artificial light at night as a new threat to pollination.

Nature. 548:206-09.

Longcore T, Rich C. 2004. Ecological light pollution. Front

Ecol Environ. 2:191-98.

MacGregor CJ, Pocock MJ, Fox R, Evans DM. 2015.

Pollination by nocturnal lepidoptera, and the effects of light pollution: a review. Ecol Entomol. 40:187-98.

Rich C, Longcore T. Editors. 2006. Ecological consequences of artificial night lighting. Washington (DC): Island Press; p. 458.

Wright HR, Lack LC. 2001. Effect of light wavelength on suppression and phase delay of the melatonin rhythm. Chronobiol Int. 18:801-08.

Wright HR, Lack LC, Kennaway DJ. 2004. Differential effects of light wavelength in phase advancing the melatonin rhythm. J Pineal Res. 36:140-44.

Zubidat AE, Haim A. 2017. Artificial light-at-night - a 
novel lifestyle risk factor for metabolic disorder and cancer morbidity. J Basic Clin Physiol Pharmacol.

553:295-313. 